\title{
PARTY AUTONOMY \\ IN ADMINISTRATIVE (JUDICIAL) PROCEEDINGS
}

\author{
NATALIYA BOCHAROVA,
}

Lomonosov Moscow State University (Moscow, Russia)

DOI: $10.21684 / 2412-2343-2016-3-2-153-163$

In 2015 in Russian Federation the new Administrative Procedure Code was adopted. The Code uses the legal terms of action proceedings (administrative claim, administrative counterclaim, administrative plaintiff and defendant etc.) and determines "dispositive" rights of parties of administrative proceedings.

The author's intention is to analyze the scope of applying of the principle of party autonomy in administrative (judicial) proceedings. The article contains the comparative analysis of the principle in civil and administrative proceedings.

Key words: administrative proceedings; civil procedure; party autonomy; dispositive principle.

Recommended citation: Nataliya Bocharova, Party Autonomy in Administrative (Judicial) Proceedings, 3(2) BRICS Law Journal 153-163 (2016).

\section{Abbreviations \\ AdmPC - The Administrative Procedure Code of the Russian Federation CivPC - The Civil Procedure Code of the Russian Federation ComPC - The Commercial Procedure Code of the Russian Federation}

In 2015 the new Administrative Procedure Code of the Russian Federation ${ }^{1}$ was adopted. Courts of general jurisdiction are now rendering justice guided by three codes: Civil Procedure Code 2 , Criminal Procedure Code and AdmPC. AdmPC came

\footnotetext{
1 The Administrative Procedure Code of the Russian Federation, hereinafter - AdmPC.

2 The Civil Procedure Code of the Russian Federation, hereinafter - CivPC.
} 
into force on the 15th of September 2015 and governs the proceedings over disputes with public element in the courts of general jurisdiction (so called administrative cases such as validity of the regulatory and individual acts, compensation for judicial delays, collection of taxes and fees etc. excluding cases concerning administrative offences). The administrative cases concerning economic (entrepreneurial) matters are adjudicated by commercial courts under the Commercial Procedure Code of the Russian Federation. ${ }^{3}$

The administrative (judicial) proceedings are not new to Russian judicial process. During long time ordinary administrative cases were adjudicated both by the courts of general jurisdiction and commercial courts under the special rules which were part of the CivPC and ComPC accordingly. The proceedings in which administrative cases were adjudicated were called public matters proceedings. Special character and differences from ordinary proceedings of the rules and proceedings are explained by the features of the public legal relationship. Disputes in administrative case arise between two unequal subjects (one of which is state authority) about public matters. The rules that govern the settlement of such disputes serve to equalize such parties. The court in such cases does not only settle disputes, but also plays an essential role in the system of divisions of powers. The courts execute control functions over the executive bodies. It explains why a court has more active role in administrative proceedings than in civil one.

The AdmPC determines the following administrative cases that should be adjudicated under its regulation by the courts of general jurisdiction:

- avoidance of the regulatory acts in whole or in part;

- avoidance of the decisions, actions (inaction) of state bodies, other state bodies, military administration bodies, local government bodies, officials, public and municipal employees;

- challenging the decisions, actions (inaction) of non-profit organizations, endowed with certain state or other public authority, including self-regulatory organizations;

- challenging the decisions, actions (inaction) of the qualifying boards of judges;

- challenging the decisions, actions (inaction) of the High Examination Committee and examination boards;

- protection of electoral rights and the right to participate in a referendum;

- compensation for the violation of the right to trial within a reasonable time or right for performance of a judicial act within a reasonable time.

- the suspension of operations or liquidation of a political party;

- termination of the activities of the media;

- the recovery of sums of money for the payment of statutory compulsory payments (including tax) and penalties on individuals;

- the hospitalization of an individual to a medical organization and others.

\footnotetext{
The Commercial Procedure Code of the Russian Federation, hereinafter - ComPC.
} 
It could be seen from this list that all administrative cases that should be adjudicated under the AdmPC are the cases related to public relationship between state bodies and persons (legal entities). When CivPC and ComPC governed the adjudication of the cases with such public elements, these Codes did not use terms of the proceedings which is initiated by means of the claim (suit-based proceedings). There were no such terms as claim, plaintiff (claimant), defendant, counterclaim, amicable agreement etc. The legislator distinguishes the civil proceedings between two equal persons concerning a civil substantive right and claim and the public matters proceedings related to a public substantive right. In the latter the court has active role, and subject of the proceedings is not private, but public interest.

The new AdmPC was drawn up in resemblance with CivPC. But for the framework authors took not the rules concerning public matter proceedings, but rules regulated ordinary suit-based proceedings. Thus legal terms related to action-based proceedings can be found now in the AdmPC that results some confusion especially when we analyze party autonomy in administrative proceedings.

Party autonomy is one of the principles of civil procedure law and international arbitration. Traditionally it is explained by way of the possibility to freely dispose one's civil law substantive rights (which are subject of the dispute). In Russian civil procedure theory we called it dispositive principle, which in the first place means the possibility to dispose one's civil substantive rights during the judicial proceedings. The substantive civil rights do not change its 'dispositive' nature even when they are challenged or defended in the court. Therefore the one who has substantive right can freely renounce it, defend it, change it, transfer it etc. The only one difference between a disposing rights in substantive legal relations and during court proceedings is that during court proceedings disposing of substantive rights has to have established procedural form. The disposition of substantive rights during civil proceedings has both substantive and procedural effects. For instance the decision of the plaintiff to renounce his substantive right would cause the termination of the proceedings; a cession results replacement of a plaintiff by his procedural successor etc.

The main rights that constitute the substance of the party autonomy in civil procedure, are the right to defend substantive right before court (bring an action), the right to determine a claim, a remedy, a defendant, a basis of the claim and cost of action, right to conclude agreement, right to change the claim or to renounce it. All these possibilities related to the claim. The claim itself (even before bringing an action before the court) is a part of any substantive private civil right. It is admitted that any claim that form a civil suit has substantive nature. It derives from substantive civil right.

Parties and first of all plaintiff who is subject of the civil private right determine the scope of adjudication in civil procedure. Ordinarily a judge has passive role or no authority concerning this matter (judex ne eat ultra petita partium ultra petita non cognoscitur). All mentioned above consequences of private law party autonomy 
come to the procedural right to dispose 1) substantive right and consequent claim (res in judicium deducta) 2) procedural mechanisms (instruments) of defend and offence (Rechtsmittel, Beweismittel). Thus two sides of the party autonomy can be allotted - substantive and formal (procedural) one. ${ }^{4}$

Likewise an action has two sides - substantive one (related to the substantive claim brought before court) and procedural one (concerning the demand to the court to settle a case), the party autonomy principle also has two sides. The substantive part of the dispositive principle refers to the possibility to freely dispose substantive (private/civil) claim during civil process. The procedural part of the principle more refers to the procedural form of such disposition. In modern civil procedure theory this procedural side of the principle of party autonomy also includes some procedural 'dispositive' rights that are not related to the claim but influence the process itself. This is right to appeal, right for enforcement proceedings, the right to choose a form of the dispute settlement and the right to choose a forum (prorogation).

Party autonomy premises that the parties are in control of specific aspects of the proceedings: the institution and continuation of the proceedings; the scope of the legal dispute; taking part in the proceedings. Party autonomy does not apply to the course of the proceedings. This is rather a matter of collaboration between the parties and the court. The principle of judicial activity implies that the court must act with restraint in respect of those aspects of the proceedings over which the parties have control under the principle of party autonomy. Party autonomy and judicial activity are limited where public policy provisions apply.

UNIDROIT Principles of Civil Procedure ${ }^{5}$ distinguish the principle of the party initiative and scope of the proceeding. According to this principle the proceeding should be initiated through the claim of the plaintiff, not by the court acting on its own motion. The scope of the proceeding is determined by the claims and defenses of the parties in the pleadings, including amendments. A party, upon showing good cause, has a right to amend its claims or defenses upon notice to other parties, and when doing so does not unreasonably delay the proceeding or otherwise result in injustice. The parties should have a right to voluntary termination or modification of the proceeding or any part of it, by withdrawal, admission, or settlement. A party should not be permitted unilaterally to terminate or modify the action when prejudice to another party would result. At the same time UNIDROIT Principles of Civil Procedure define the principle of the court responsibility for direction of the proceeding. Commencing as early as practicable, the court should actively manage the proceeding, exercising discretion to achieve disposition of the dispute fairly, efficiently, and with reasonable speed.

4 Васьковский Е.В. Учебник гражданского процесса [E. Vaskovski, Civil Procedure Textbook] 97 (Moscow 1917).

ALI / UNIDROIT Principles of Transnational Civil Procedure, available at <http://www.unidroit.org/ english/principles/civilprocedure/ali-unidroitprinciples-e.pdf>. 
Usually the principle of the judge's case management (or active role of the judge) is considered along with the principle of adversarial proceedings. Meanwhile active or passive role of the judge during a party's disposition of substantive or procedural rights is determinant characteristic of the proceeding itself.

When we proceed to examine the principle of party autonomy in administrative proceedings we should start from this basic conception of this principle in civil procedure. It is obvious that the nature of private and public rights is different. There is the possibility to dispose public rights (for instance to refrain from disposition of a public right), but the scope of such disposition is incomparably less than for civil rights $^{6}$.

Public relations by the legal nature are subordinated. Russian scholars admit that public right unlike private one does not include the possibility to claim something from the state body. The private person has only right to appeal to the court for protection against unlawful acts of public authorities and official'. It means that the public autonomy in administrative proceedings can be described only from the procedural side.

The AdmPC contains the list of principles that governs administrative justice (art. 6), which includes such principles as independence of the judiciary; equality before the law and the courts; the legality and justice of adjudication of administrative cases; the implementation of the administrative proceedings within a reasonable time and the enforcement of judgments in administrative cases within a reasonable time; transparency and openness of the trial; the immediacy of the trial; equality of parties and adversarial administrative proceedings with the active role of the court. ${ }^{8}$ The principle of party autonomy is not mentioned in this list. Russian scholars acknowledge that in some extent this principle should be applied to the adjudication of administrative cases. ${ }^{9}$ Meanwhile this principle is confined (in more extent than in civil procedure) by the idea of the active role of the judge. The active role of the court in administrative justice is manifested in the implementation not only of the principle of adversarial proceedings but also other principles. In particular, the

6 More about the nature of the disposition of civil and public rights refer to Третьяков С.В. О проблеме догматической квалификации «правомочия распоряжения». Основные проблемы частного права [Tretyakov S.V. About a problem of the dogmatic classification of the 'possibility of disposition'. Main problems of private law] 317-344 (Moscow 2010).

7 Рожкова М.А., Глазкова М.Е., Савина М.А. Актуальные проблемы унификации гражданского процессуального и арбитражного процессуального законодательства [Rozhkova M.A., Glazkova M.E., Savina M.A. Contemporary problems of unification of the civil and arbitrazh procedure legislation] (Infra-M 2015).

8 It is worth to mention that neither ComPC or CivPC can boast of such list.

9 Комментарий к Кодексу административного судопроизводства Российской Федерации (постатейный, научно-практический) [Annotation to the Code of administrative procedure] (V.V. Yarkov ed., Statut 2016); Воронов А.Ф. Гражданский процесс: эволюция диспозитивности [Voronov A.F. The evolution of the dispositive principle] (Statut 2007). 
specificity of the party autonomy principle in administrative proceedings assumes, in contrast to the civil proceedings, that the court overseeing the development of the judicial process and the disposition of the substantive rights.

The definition of the party autonomy principle can be found in the decision of the Russian Constitutional Court: "... party autonomy means that procedural relationships arise, change and terminate mainly on the initiative of those directly involved into substantive relations at issue, and which have the possibility to dispose of procedural rights by means of the court.".10 The Constitutional Court noted that the restriction of the principle of party autonomy, due to the specifics of a administrative disputes is permissible only in cases where the nature of the dispute public relations does not imply the possibility of free disposal of substantive right.

Analysis of the position of the Constitutional Court leads to several important conclusions. Firstly, procedural relationships arise, change and terminate mainly on the initiative of those directly involved into controversial substantive relations. Secondly, within the framework of proceedings party of the disputed substantive relations can dispose of both the procedural rights and controversial substantive right. Thirdly, the court plays active role and controls over the disposition of rights. Fourthly, the party autonomy can be applied in administrative proceedings only to the cases where substantive right can be disposed.

The party autonomy principle in civil procedure includes several so-called dispositive rights such as

- the right to choose a form of the dispute settlement;

- the right to choose a forum (prorogation);

- the right to apply to the court (nemo judex sine actore; nemo invitus agere cogitur)

- the right to determine a claim, a respective remedy and suitable grounds of the claim;

- the right to claim prejudgment remedies which can guarantee the enforceability of the judicial decision

- the right for recalling or renunciation of a claim;

- the right to change a claim (claim itself, grounds of the claim and its size);

- the right to bring counterclaim;

- the right of the defendant to accept a claim;

- the right to conclude an amicable agreement;

- the right to appeal (incl. the right to determine the scope of appealing proceedings);

- the right for enforcement proceedings and others.

Further we would analyze if some of these dispositive rights can be exercised in administrative procedure in comparison with civil procedure.

10 The Decision of the Constitutional Court of Russian Federation on 16 July 2004 No. 15-П. 
The right to bring an administrative action, to determine claim and its basis. In civil procedure a plaintiff has the right to determine the scope of adjudication by defining the claim, the specific remedy and the underlying grounds of the claim. For instance, in case of non-performance of the contract the seller has opportunity to choose between claims to perform a contract or to cancel an agreement and demand his property back. The basis of the claim is usually arisen from the substantive law that defines the legal factual circumstances that origin the substantive right. In some rare cases the substantive law involves different basis for the origin of the same right. In this case a plaintiff has possibility to choose the basis of the claim. Also in civil procedure a plaintiff can define the cost of the claim and can combine several claims. As a rule a court has no right to overstep the limits of the claim(s) that is defined by a plaintiff." Here we have a logical trap. In civil procedure the court ex officio applies law. Law defines the specific remedy to defend the substantive right and underlying grounds to be basis for the claim. Thus by applying law a judge can qualify if the remedy and the basis were determined right by the plaintiff. And if not, can the court ex officio change the remedy (in case of the competition of actions) or the basis for the purpose of just adjudication. There is not a one-valued decision of this problem. The balance between a party autonomy and the active role of a judge should be examined in every different case.

In administrative proceedings there is also strict rule that there is no adjudication without a claim. In all kind of cases, which are arisen in administrative procedure, the court needs an administrative action from an administrative claimant to commence proceedings. De jure administrative claimant similar to civil procedure has right to determine his claim and underlying grounds of it. But de facto the AdmPC defines almost all possible claims that can be brought before the court and its possible grounds.

First of all mentioned above the list of cases that are heard by the court in administrative proceedings is formed on the basis of sorts of claims that can be brought before court. Thus there is no opportunity to choose a specific remedy, because each case has its own fixed formal statement of claim that initiates proceedings. For instance, a claim of an avoidance of the regulatory acts in whole or in part; a claim of an avoidance of the decisions, actions (inaction) of state bodies, other state bodies, military administration bodies, local government bodies, officials, public and municipal employees; a claim for compensation for the violation of the right to trial within a reasonable time or right for performance of a judicial act within a reasonable time etc. Thus in civil procedure a remedy can be chosen by a plaintiff from remedies established by substantive law. In administrative proceedings the

11 There is some exclusion, which is determined by the substantive law. For instance, art. 166 of the Civil Code of Russian Federation determines that the court may apply the consequences of the invalidity of a void transaction on its own initiative, if it is necessary for the protection of public interests, and in other cases provided by law. 
formal statement of claim is define in formulas in the AdmPC. That does not mean any restriction of the party autonomy. It just reveals that the substance of substantive public rights in administrative legal relations that gives no choices of remedy for a claimant.

The same can be said about the choice of a basis of a claim. Determined by the AdmPC claims have fixed by this Code grounds. For instance, the basis for the claim of an avoidance of the regulatory acts in whole or in part is determined by the art. 209 of the AdmPC (to avoid an act a plaintiff should indicate the fact of application of the challenged normative legal act to the plaintiff or the fact that a plaintiff is subject to administrative relations regulated by this act; the fact of violation of the rights, freedoms and legitimate interests of the person who filed a lawsuit; the fact that normative act contradicts the act that prevails the challenged act in legal force). Further the court is not bound by the grounds, indicated by a plaintiff. Art. 213 of the AdmPC determines the facts, that should be ascertained by the court whatever grounds were specified by a plaintiff. For instance in for the claim of an avoidance of the regulatory acts the court should found out 1 ) whether the rights, freedoms and legal interests of the plaintiffs were violated; 2 ) whether the normative legal acts conforms established requirements concerning a) the competence of the body for the adoption of regulatory legal acts; b) the form of the normative legal acts; c) the procedure for adoption of the contested normative legal act; $g$ ) the order of publication, state registration (if the state registration of normative legal acts of data provided by the legislation of the Russian Federation) and their entry into force; 3 ) compliance of the contested normative legal act with a normative legal acts with higher legal force.

Right to choose a defendant. In civil procedure it is essential right of a plaintiff to choose a person to which its claim is addressed. In administrative proceedings there is some exclusion from this general rule. The art. 221 of the AdmPC sets that in the administrative case in which the decisions, actions (inaction) of an official, state or municipal employee is challenging the court has to bring to the trial as the second defendant the appropriate administrative authority, where official, state or municipal employee holds an office.

The art. 43 of the Code establishes that if during pre-trial stage of the adjudication the court determines that the plaintiff brought an action against wrong person, the court can replace the defendant with the plaintiff's consent. If the administrative claimant does not agree to replace the administrative defendant the court may, without the consent of the plaintiff's bring to trial that person as the second defendant.

These rules violate the traditional principle of party autonomy and grant the court the right to define defendant in administrative cases or, in other words, to bring a new action itself without consent of the administrative claimant. The court prejudges the final conclusion about the person who holds public obligations. 
The right to renounce a claim. According to the art. 46 of the AdmPC administrative plaintiff is entitled to renounce a claim in whole or in part before a judicial act that terminates the proceedings in a court of first instance or appellate court.

The Court does not accept the renunciation it contradicts the AdmPC, other federal laws or violating the rights of others.

The article 194 of the AdmPC determines that the renunciation of a claim leads to the termination of proceedings (means the plaintiff could not bring the same action before court).

The same rules can be found in CivPC and ComPC. We can see in these rules the balance between the principle of active judge and the possibility to freely dispose of substantive rights. A judge has to control the legitimacy of the plaintiff's actions. AdmPC and ComPC determine that the right to renounce of a claim can be dispose only before a judgement has res judicata effect (in first and appellate instances). CivPC does not impose such restrictions.

The article 213 of the AdmPC determines that if a court adjudicates a case concerning an avoidance of the regulatory acts in whole or in part, renunciation of a claim does not entail the obligation of the court to terminate proceedings. In such cases a court fulfil obligation not only to adjudicate a dispute, but to carry out control over state executive authority. In such cases an administrative plaintiff has right to renounce but at the same time the court has two options: 1) to terminate proceedings in case if there are no public interests that prevent a court from taking this renunciation or 2 ) to continue adjudication.

Rights of a defendant for counterclaim and acceptance of a claim. The CivPC determines the right of a defendant to bring a counterclaim in case when 1) counterclaim is directed to set off the initial requirements; 2 ) satisfaction of the counterclaim excludes fully or partly satisfaction of the initial claim; 3 ) there is mutual relationship between the counterclaim and the initial claims their joint adjudication will lead to a more rapid and proper settlement of the dispute.

The art. 131 of the AdmPC determines the same grounds of bringing an administrative counterclaim. De facto, virtually none of the administrative cases gives possibility to bring a counterclaim.

Amicable agreement. The art. 39 of the CivPC defines the right of the party to conclude an amicable agreement (compromise settlement of the dispute). The new AdmPC determines so called agreement on reconciliation that can be concluded by the parties. The art. 46 of the AdmPC sets that the court does not accept the agreement for reconciliation, if such agreement is expressly prohibited by law, contrary to the merits of the administrative proceedings or violate the rights of others. According to the art. 137 of the AdmPC reconciliation of the parties can only affect their rights and obligations. Such agreement is allowed only in the case of the admissibility of mutual concessions of the parties. The Court does not approve the agreement on the reconciliation of the parties, if the conditions are contrary to the law 
or violate the rights, freedoms and legitimate interests of others. After approving of the reconciliation agreement the administrative proceedings are terminated in whole or in relevant part. The reconciliation agreement is prohibited in the cases concerning avoidance of the regulatory acts in whole or in part (art. 213 of the AdmPC).

The amicable agreement in civil procedure is a civil law agreement between two parties. The legal nature of the reconciliation agreement in administrative proceedings is to be found. Some Russian scholars doubt that the subject matter of the administrative proceedings is substantive right. ${ }^{12}$ The possibility to reconciliation between parties of the public matter proceedings is a new idea for the Russian procedural law. The act of the Plenum of the Supreme Court of Russian Federation defined that the question of the legality of an act of public authority cannot be affected by any agreement between the applicant and state body. ${ }^{13}$ Procedural rules determine only the possibility and the form of a reconciliation agreement. It is questionable what law will regulate the content of such agreements and what would be their subject. The Act of the Plenum of the High Commercial Court defined that only some procedural aspects can be subject of such agreement: "... arbitration courts should take into account that according to the reconciliation agreement may include: recognition of the circumstances of the case, the parties' agreement on the circumstances of the case; the parties' agreement containing qualification of transaction made by a person involved in the case, or the status and nature of the activities of that person; partial or full waiver, a partial or complete acceptance of the claims requirements an agreement of the assessment of the circumstances as a whole or in separate parts."14

Right to appeal. The AdmPC grants right to appeal to parties of administrative proceedings. The main difference between civil and administrative proceedings in this matter is that in administrative procedure parties has no right to define the scope of appealing proceedings. According to the art. 308 of the AdmPC the appellate court judge an administrative case in full and is not bound by the grounds and arguments set out in the appeal or objections regarding appeal.

The brief analyze of the applying of the principle of party autonomy in administrative proceedings shows that the AdmPC does not logically develop this idea. Thoughtless reproduction of the action of the principle from the suit-based ordinary proceedings could not work because of the particular nature of the public relations that are subject of the adjudication.

12 Шерстюк В.М. К десятилетию АПК РФ: о предмете деятельности арбитражного суда первой инстанции по делам, возникающим из административных и иных публичных правоотношений, 3 Вестник гражданского процесса (2012) [Sherstyuk V.M. 10 year of the ComPC: about the subject of adjudication of the public matter and administrative cases, 3 Vestnik grazhdanskogo processa (2012)].

13 The Act of the Plenum of the Supreme Court, 10 Feb. 2009, No. 2.

14 The Act of the Plenum of the High Commercial Court, 18 July 2014, No. 50. 
Consequently the inconsiderate use of such terms of civil procedure as claim, plaintiff, defendant, counterclaim resulted that the legislator tries to apply the institute of claim (action) in its substantive meaning to the proceedings with public nature.

\section{References}

Воронов А.Ф. Гражданский процесс: эволюция диспозитивности [Voronov A.F. The evolution of the dispositive principle] (Statut 2007).

Комментарий к Кодексу административного судопроизводства Российской Федерации (постатейный, научно-практический) [Annotation to the Code of administrative procedure] (V.V. Yarkov ed., Statut 2016).

Рожкова М.А., Глазкова М.Е., Савина М.А. Актуальные проблемы унификации гражданского процессуального и арбитражного процессуального законодательства [Rozhkova M.A., Glazkova M.E., Savina M.A. Contemporary problems of unification of the civil and arbitrazh procedure legislation] (Infra-M 2015).

Третьяков С.В. О проблеме догматической квалификации «правомочия распоряжения». Основные проблемы частного права [Tretyakov S.V. About a problem of the dogmatic classification of the "possibility of disposition". Main problems of private law] 317-344 (Moscow 2010).

Шерстюк В.М. К десятилетию АПК РФ: о предмете деятельности арбитражного суда первой инстанции по делам, возникающим из административных и иных публичных правоотношений, 3 Вестник гражданского процесса (2012) [Sherstyuk V.M. 10 year of the ComPC: about the subject of adjudication of the public matter and admi-nistrative cases, 3 Vestnik grazhdanskogo processa (2012)].

\section{Information about the author}

Bocharova Nataliya (Moscow, Russia) - Associate Professor of Civil Procedure at the Faculty of Law, Moscow State University (1 Leninskie Gory, bldg. 13-14, Moscow, 119991, GSP-1, Russia; practicidad@gmail.com). 